\title{
AN ADVANCED CAST-AND-WROUGHT SUPERALLOY (TMW-4M3) FOR TURBINE DISK APPLICATIONS BEYOND $700^{\circ} \mathrm{C}$
}

\author{
Y. GU ${ }^{1}$, Z. Zhong ${ }^{1}$, Y. Yuan ${ }^{2}$, T. Osada ${ }^{1, a}$, C. Cui ${ }^{1, b}$, T. Yokokawa ${ }^{1}$ and H. Harada ${ }^{2}$ \\ ${ }^{1}$ High Temperature Materials Unit, National Institute for Materials Science (NIMS), \\ 1-2-1 Sengen, Tsukuba Science City, Ibaraki 305-0047, Japan \\ ${ }^{2}$ Environment and Energy Materials Division, NIMS, 1-2-1 Sengen, Tsukuba Science City, Ibaraki 305-0047, Japan \\ a now at Research Center for Green Materials Innovation, Yokohama National University, Yokohama 240-8501, Japan \\ ${ }^{\mathrm{b}}$ now at Institute of Metal Research, Shenyang 110016, China
}

Keywords: Disk Superalloy, Cast \& Wrought, TMW-4M3, Microstructure, Mechanical Properties

\begin{abstract}
A new cast \& wrought $(\mathrm{C} \& \mathrm{~W})$ superalloy, designated as TMW4M3, has been developed on the basis of our innovative concept for applications of turbine disks and other components beyond $700^{\circ} \mathrm{C}$. TMW-4M3 contains $25 \mathrm{wt} \%$ Co and $6.2 \mathrm{wt} \% \mathrm{Ti}$, which are higher than that of commercial disk alloys. Full-scale pancakes with $400 \mathrm{~mm}$ in diameter and $50 \mathrm{~mm}$ in thickness were manufactured from TMW-4M3 alloy via a process route of triplemelting, billet making and disk forging. The investigations on the microstructure and the mechanical properties including tensile strength, creep resistance, fatigue strength and resistance to crack propagation of TMW-4M3 indicate that the alloy provides a $100 \mathrm{MPa}$ advantage in $0.2 \%$ yield strength at $750^{\circ} \mathrm{C}$ and a $76^{\circ} \mathrm{C}$ temperature advantage in $0.2 \%$-strain creep performance loaded under 630MPa over Alloy 720Li (U720Li). The alloy maintains its $\gamma / \gamma^{\prime}$ two-phase structure exposed at $750{ }^{\circ} \mathrm{C}$ for up to 5000 hours. The increment of strength at high temperatures is attributed to the precipitation hardening caused by higher volume fraction of the secondary $\gamma^{\prime}$ precipitates and twin boundary strengthening as a result of high density of annealing twins.
\end{abstract}

\section{Introduction}

To meet high requirements of mechanical properties in turbine components of advanced engines, a new kind of cast and wrought $(\mathrm{C} \& \mathrm{~W}) \mathrm{Ni}-\mathrm{Co}$ base superalloys (registered as $\mathrm{TMW}^{\circledR}$ alloy) has been designed recently for the applications of turbine disk and high-pressure compressor beyond $700^{\circ} \mathrm{C}$ [1-4]. TMW alloy normally has a Co content of 22 to $31 \mathrm{wt} . \%$, a Ti content of 5.4 to 7.4 wt. $\%$ and a gamma prime $\left(\gamma^{\prime}, \mathrm{L1}_{2}\right)$ weight volume fraction of 0.4 to 0.5 .

Preliminary results indicate that TMW-4 alloy has the strongest creep resistance among TMW alloys and provides a $32^{\circ} \mathrm{C}$ temperature advantage in strain-rupture performance over Alloy 720Li [1]. However, small amount of eta $\left(\eta, \mathrm{Ni}_{3} \mathrm{Ti}\right)$ phase, a topologically close packed (TCP) phase, exists in the TMW-4 alloy after homogenization at $1220^{\circ} \mathrm{C}$ and then aging at temperatures ranging from $1000^{\circ} \mathrm{C}$ to $1175^{\circ} \mathrm{C}$ for hours [5]. Normally, the existence of $\eta$ phase has deleterious effects on the alloy's ductility and its notched stress rupture strength. It is reported that high $\mathrm{Ti}$ content, especially high $\mathrm{Ti} / \mathrm{Al}$ composition ratio, may promote the phase transition from $\gamma^{\prime}$ to $\eta$ in alloys, while high $\mathrm{Cr}$ level may also promote the formation of TCP phase.

In comparison with TMW-4 alloy, TMW-2 alloy shows superior workability and phase stability (no $\eta$ phase), but less creep resistance and weaker in other mechanical properties [2]. Therefore, a new TMW alloy, TMW-4M3, has been designed by decreasing $\mathrm{Cr}$ content slightly while keeping the $\mathrm{Ti}+\mathrm{Al}$ content and the Ti/Al composition ratio of TMW-2 alloy for the purpose of maintaining its good phase stability and the workability. Furthermore, the contents of Co, $\mathrm{W}$ and Mo were increased slight for improving its mechanical properties (Table I).

This paper examines the phase equilibria and the mechanical properties of TMW-4M3 and Alloy 720Li processed and heat treated under same conditions. The results indicate that TMW$4 \mathrm{M} 3$ is a promising $\mathrm{C} \& \mathrm{~W}$ superalloy for the applications of turbine components beyond $700^{\circ} \mathrm{C}$.

\section{Materials and Experimental Procedure}

Chemical compositions of TMW-2, TMW-4M3 and Alloy U720 $\mathrm{Li}$ are listed in Table I.

Materials for this study were melted and processed by Mitsubishi Materials Corporation, Japan. Ingots were produced through primary vacuum induction melting (VIM), electro-slag re-melting (ESR) and vacuum arc re-melting (VAR). Each of VAR ingots was $500 \mathrm{~mm}$ in diameter and weights about $1.7 \mathrm{ton}$. The surfaces of the VAR ingots were checked carefully and no evidence of instability during the re-melting process and defects such as

Table I. Nominal Compositions of Tested Alloys (weight percent)

\begin{tabular}{|c|c|c|c|c|c|c|c|c|c|c|}
\hline Alloy & Co & Cr & W & Mo & Ti & Al & Zr & C & B & Ni \\
\hline TMW-2 & 21.8 & 14.4 & 1.1 & 2.7 & 6.2 & 2.3 & 0.03 & 0.02 & 0.02 & Bal. \\
\hline TMW-4M3 & 25.0 & 13.5 & 1.2 & 2.8 & 6.2 & 2.3 & 0.03 & 0.02 & 0.02 & Bal. \\
\hline U720Li & 15.0 & 16.0 & 1.3 & 3.0 & 5.0 & 2.5 & 0.03 & 0.02 & 0.02 & Bal \\
\hline
\end{tabular}


cracks, pores or heavy segregations were observed. Chemical analysis showed that most of the elemental compositions were well controlled to the nominal values, although $\mathrm{Al}$ and Ti contents slightly varied within the VAR ingots, which might be caused by the ESR process. The VAR ingots homogenized below the $\gamma$ ' solvus temperature were forged successfully and the final billets of $200 \mathrm{~mm}$ diameter were obtained without surface cracks. The microstructure was fine and homogeneous enough for further processing. Several pancake disks of tested alloys were forged at the same deformation condition under $1100^{\circ} \mathrm{C}$, which are $400 \mathrm{~mm}$ diameter and $50 \mathrm{~mm}$ thickness as shown in Figure 1.

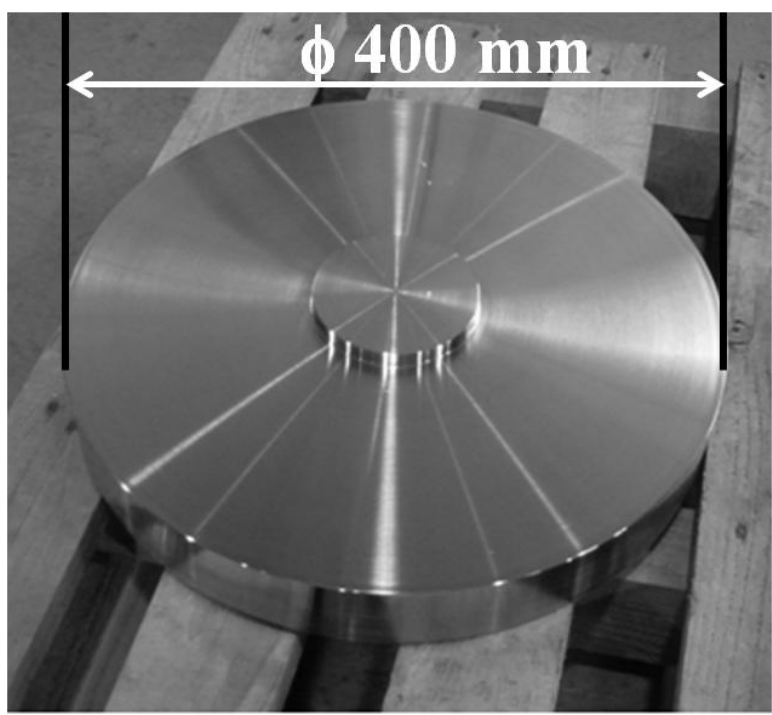

Figure 1. Pancake forged from TMW-4M3 alloy

All specimens were cut from the pancakes. The samples of Alloy $720 \mathrm{Li}$ were treated with its standard heat-treatment condition while the samples of TMW-4M3 were treated under two conditions as indicated in Table II.

Table II. Heat Treatment Schedules of the Tested Alloys

\begin{tabular}{|l|l|}
\hline \multicolumn{1}{|c|}{ Alloy } & Heat Treatment Conditions \\
\hline Alloy $720 \mathrm{Li}$ & $1100^{\circ} \mathrm{C} / 4 \mathrm{~h} / \mathrm{OQ}+650^{\circ} \mathrm{C} / 24 \mathrm{~h} / \mathrm{AC}+760^{\circ} \mathrm{C} / 16 \mathrm{~h} / \mathrm{AC}$ \\
\hline TMW-4M3-1 & $1100^{\circ} \mathrm{C} / 4 \mathrm{~h} / \mathrm{OQ}+650^{\circ} \mathrm{C} / 24 \mathrm{~h} / \mathrm{AC}+760^{\circ} \mathrm{C} / 16 \mathrm{~h} / \mathrm{AC}$ \\
\hline TMW-4M3-2 & $1120^{\circ} \mathrm{C} / 4 \mathrm{~h} / \mathrm{OQ}+650^{\circ} \mathrm{C} / 24 \mathrm{~h} / \mathrm{AC}+760^{\circ} \mathrm{C} / 16 \mathrm{~h} / \mathrm{AC}$ \\
\hline
\end{tabular}

Note: AC — Air Cooling, OQ-Oil Quench
The phase constitution and the microstructure evolution caused by heat treatment and thermal exposure were observed by optical microscopy, X-ray diffraction, scanning electron microscopy (SEM) and transmission electron microscopy (TEM). The specimens were prepared by metallographic polishing followed by etching in a solution of Marble reagent $\left(10 \mathrm{~g} \mathrm{CuSO}_{4}+50 \mathrm{ml} \mathrm{HCl}\right.$ $+50 \mathrm{ml} \mathrm{H}_{2} \mathrm{O}$ ). TEM samples were electrochemically polished with a twin jet polisher using a solution of $83 \%$ ethanol, $7 \%$ glycerol and $10 \%$ perchloric acid at $-25^{\circ} \mathrm{C}$.

Mechanical testings were performed according to ASTM E8/E21, ASTM E139, ASTM E606 and ASTM E647 standard test methods for tensile, creep, low-cycle fatigue (LCF) and fatigue crack growth rate (FCGR), respectively,

\section{Results and Discussion}

Microstructure and Microstructural Stability

The equilibrium phases of the TMW-4M3 at $760{ }^{\circ} \mathrm{C}$ were analyzed by using the Thermo-Calc program (Version $\mathrm{N}$ ) and $\mathrm{Ni}$ RUMN database (Thermo-Calc Software, Sweden) as shown in Figure 2. Several key thermodynamic data are listed in Table III

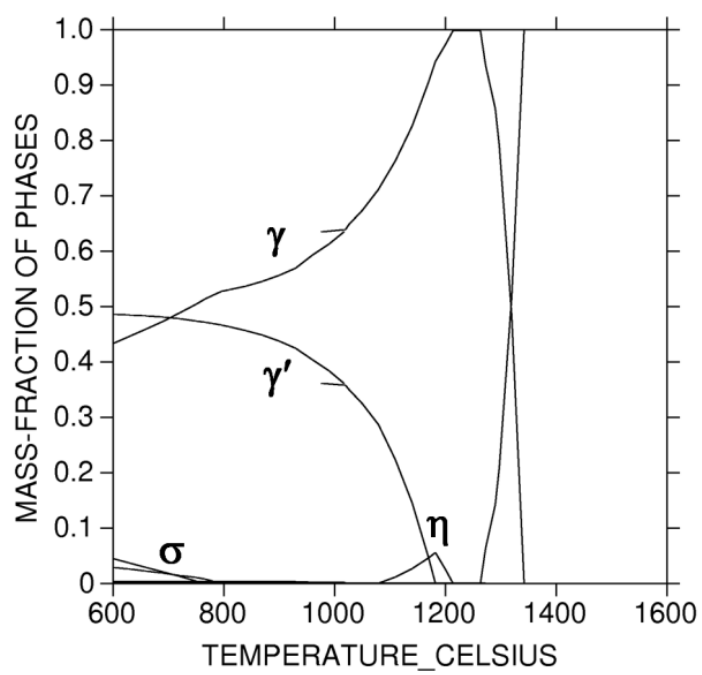

Figure 2. Calculated phase fraction $v s$ temperature diagram of TMW-4M3.

Table III. Key Thermodynamic Data of TMW-4M3 Alloy

\begin{tabular}{|c|c|c|c|c|c|c|}
\hline Alloy & $\begin{array}{c}\text { Liquid } \\
{ }^{\circ} \mathrm{C}\end{array}$ & $\begin{array}{c}\text { Solidus } \\
{ }^{\circ} \mathrm{C}\end{array}$ & $\begin{array}{c}\sigma \text { Region } \\
{ }^{\circ} \mathrm{C}\end{array}$ & $\begin{array}{c}\eta \text { Region } \\
{ }^{\circ} \mathrm{C}\end{array}$ & $\begin{array}{c}\gamma^{\prime} \text { solvus } \\
{ }^{\circ} \mathrm{C}\end{array}$ & $\begin{array}{c}\gamma^{\prime} \text { wt. \% } \\
\text { at } 750^{\circ} \mathrm{C}\end{array}$ \\
\hline TMW-4M3 & 1343 & 1273 & $570-752$ & $1083-1218^{\circ} \mathrm{C}$ & 1183 & $49.4 \%$ \\
\hline
\end{tabular}


TMW-4M3 was predicted to contain $\gamma, \gamma^{\prime}, \eta$ (from $1083^{\circ} \mathrm{C}$ to $1218{ }^{\circ} \mathrm{C}$ ), sigma $(\sigma)$ (existed from $570^{\circ} \mathrm{C}$ to $752{ }^{\circ} \mathrm{C}$ ), and some minor phases such as carbide and boride.

However, no $\eta$ and $\sigma$ phases were found in the sample treated at $1200^{\circ} \mathrm{C} / 1 \mathrm{~h}$ and then cooled to $760^{\circ} \mathrm{C}$ with a cooling rate of $0.5^{\circ} \mathrm{C} / \mathrm{h}$ (Figure 3), which passed the $\eta$ phase forming region in the Thermo-Calc result and TMW-4 alloy [5]. Furthermore, $\eta$ and $\sigma$ phases did not existed in the samples treated at $1200^{\circ} \mathrm{C} / 1 \mathrm{~h} / \mathrm{WQ}$ and then exposed at $850^{\circ} \mathrm{C}, 750^{\circ} \mathrm{C}$ and $650^{\circ} \mathrm{C}$ for 5000 hours, which indicates that TMW-4M3 alloy has better microstructural thermal stability than that of TMW-4 alloy.

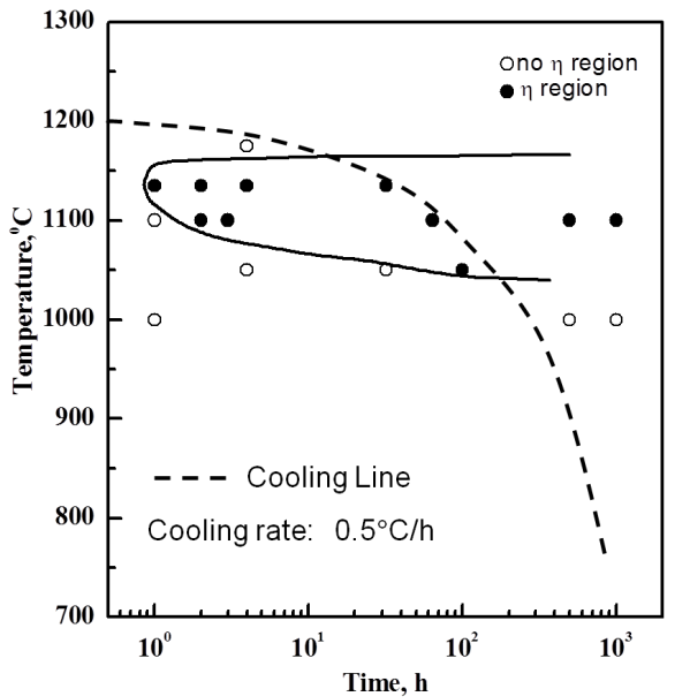

Figure 3. TTT curve of the $\eta$ phase forming region in TMW$4[5]$ and cooling line in TMW-4M3.

Microstructural features of each heat treated alloys are shown in Figure 4. The grain size and other characters are listed in Table IV. It is noted that the grain size for TMW-4M3-2 treated at $1120^{\circ} \mathrm{C} / 4 \mathrm{~h}$ is $10.6 \mu \mathrm{m}$, which is almost the same as that of Alloy $720 \mathrm{Li}$ treated at its standard heat-treatment condition. Meanwhile, high density annealing twins were found in the heat treated TMW-
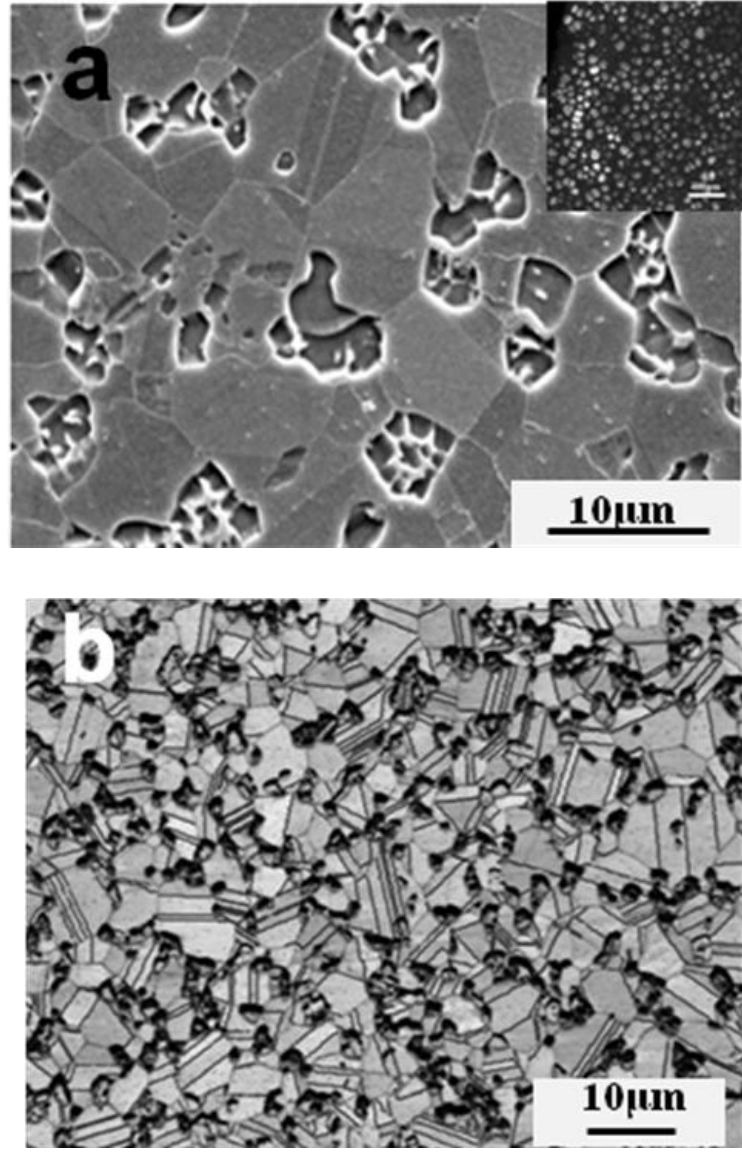

Figure 4. Typical microstructures after heat treatment: (a) Alloy 720Li; (b)TMW-4M3-2.

4M3 alloy. The total twin length in an area of $150 \times 150 \mu \mathrm{m}$ was $2.45,5.03$ and $5.15 \mathrm{~mm}$ in Alloy U720Li, TMW-4M3-1 and TMW-4M3-2, respectively (Figure 4b). High twin formability may be caused by low stacking fault energy (SFE) in TMW-4M3 alloy [6].

Table IV. Microstructural Characteristics of Tested Alloys

\begin{tabular}{|c|c|c|c|c|c|c|c|c|}
\hline \multirow[b]{2}{*}{ Alloy } & \multirow{2}{*}{$\begin{array}{l}\text { Grain Size } \\
\quad(\mu \mathrm{m})\end{array}$} & \multicolumn{2}{|c|}{ Primary $\gamma^{\prime}$} & \multicolumn{2}{|c|}{ Secondary $\gamma^{\prime}$} & \multicolumn{2}{|c|}{ Tertiary $\gamma^{\prime}$} & \multirow{2}{*}{$\begin{array}{c}\text { Annealing Twins } \\
\text { Length }(\mathrm{mm}) \\
\left(\text { in } 150 \times 150 \mu \mathrm{m}^{2}\right)\end{array}$} \\
\hline & & $\begin{array}{c}\text { Fraction } \\
\text { (vol.\%) }\end{array}$ & $\begin{array}{l}\text { Size } \\
(\mu \mathrm{m})\end{array}$ & $\begin{array}{c}\text { Fraction } \\
\text { (vol.\%) }\end{array}$ & $\begin{array}{l}\text { Size } \\
(\mathbf{n m})\end{array}$ & $\begin{array}{c}\text { Fraction } \\
\text { (vol.\%) }\end{array}$ & $\begin{array}{l}\text { Size } \\
(\mathbf{n m})\end{array}$ & \\
\hline 4M3-1 & 8.7 & 16.9 & $<2.5$ & 30.0 & 60 & $\sim 2.1$ & 10 & 5.03 \\
\hline $4 \mathrm{M} 3-2$ & 10.6 & 14.5 & $<2.5$ & 31.5 & 70 & $\sim 3.0$ & 10 & 5.15 \\
\hline U720Li & 10.2 & 13.1 & $<2.5$ & 29.4 & 90 & $\sim 2.5$ & 10 & 2.45 \\
\hline
\end{tabular}


Table V. Tensile Properties of Tested Alloys

\begin{tabular}{|c|c|c|c|c|c|c|c|c|c|c|c|c|}
\hline \multirow{2}{*}{ Alloy } & \multicolumn{4}{|c|}{$20^{\circ} \mathrm{C}$} & \multicolumn{4}{|c|}{$650^{\circ} \mathrm{C}$} & \multicolumn{4}{|c|}{$750^{\circ} \mathrm{C}$} \\
\hline & $\begin{array}{c}\text { YS } \\
\text { (MPa) }\end{array}$ & $\begin{array}{c}\text { UTS } \\
\text { (MPa) }\end{array}$ & $\begin{array}{l}\text { EL } \\
\%\end{array}$ & $\begin{array}{c}\text { R.A. } \\
\%\end{array}$ & $\begin{array}{c}\text { YS } \\
\text { (MPa) }\end{array}$ & $\begin{array}{l}\text { UTS } \\
\text { (MPa) }\end{array}$ & $\begin{array}{l}\text { EL } \\
\%\end{array}$ & $\begin{array}{c}\text { R.A. } \\
\%\end{array}$ & $\begin{array}{c}\text { YS } \\
\text { (MPa) }\end{array}$ & $\begin{array}{c}\text { UTS } \\
\text { (MPa) }\end{array}$ & $\begin{array}{l}\text { EL } \\
\%\end{array}$ & $\underset{\%}{\text { R.A. }}$ \\
\hline U720Li & 1175 & 1584 & 22.5 & 23.0 & 1052 & 1319 & 34.0 & 33.0 & 915 & 1045 & 20.4 & 23.5 \\
\hline TMW-4M3-1 & 1185 & 1638 & 14.0 & 13.6 & 1074 & 1334 & 14.4 & 12.4 & 1007 & 1122 & 9.9 & 10.5 \\
\hline TMW-4M3-2 & 1165 & 1615 & 13.5 & 13.7 & 1049 & 1422 & 14.3 & 14.6 & 1008 & 1131 & 9.5 & 9.8 \\
\hline
\end{tabular}

\section{Tensile Strength and Creep Properties}

The tensile tests were conducted at room temperature $\left(20^{\circ} \mathrm{C}\right)$, $650^{\circ} \mathrm{C}$ and $750^{\circ} \mathrm{C}$, respectively. $0.2 \%$ yield strength (YS), ultimate tensile strength (UTS), elongation (EL) and reduction of area (RA) are given in Table $\mathrm{V}$. Below $650^{\circ} \mathrm{C}$, all tested alloys had comparable tensile YS while the YS strength of TMW-4M3 decreased by about $2 \%$ with the increase of the solution temperature. At $750{ }^{\circ} \mathrm{C}$, YS and UTS of TMW-4M3 treated under two conditions had almost the same strength level and were about $100 \mathrm{MPa}$ higher than that of Alloy 720Li.

Stress-rupture tests were conducted in air under loads ranging from $480 \mathrm{MPa}$ to $840 \mathrm{MPa}$ in temperatures ranging from $650{ }^{\circ} \mathrm{C}$ to $760{ }^{\circ} \mathrm{C}$. TMW-4M3 alloy treated under two conditions exhibited a great improvement in the creep resistance compared with Alloy U720Li at all tested temperatures and stresses (Table VI). By comparison of the life to $0.2 \%$ strain at the stress level of $630 \mathrm{MPa}$,

Table VI. Tensile Creep Properties of Tested Alloys

\begin{tabular}{|c|c|c|c|c|c|c|}
\hline \multirow{2}{*}{\multicolumn{2}{|c|}{$\mathrm{P}_{r_{0 p} .}$ Temp. }} & \multirow{3}{*}{$\begin{array}{c}650^{\circ} \mathrm{C} \\
840 \\
8.4\end{array}$} & \multicolumn{3}{|c|}{$725^{\circ} \mathrm{C}$} & \multirow{3}{*}{$\begin{array}{c}760^{\circ} \mathrm{C} \\
480 \\
1\end{array}$} \\
\hline & & & \multirow{2}{*}{$\frac{480}{10.5}$} & \multirow{2}{*}{$\frac{630}{1.2}$} & \multirow{2}{*}{$\begin{array}{l}840 \\
0.09\end{array}$} & \\
\hline I ifo & $720 \mathrm{Li}$ & & & & & \\
\hline $0.2 \%$ crept strain, & 4M3-1 & 458 & 229 & 74 & 1 & 18 \\
\hline & 4M3-2 & 298 & 304 & 48 & 0.8 & 21 \\
\hline \multirow{3}{*}{$\begin{array}{l}\text { Rupture life } \\
\text { (hour) }\end{array}$} & $720 \mathrm{Li}$ & 183 & 203 & 36 & 2.8 & 29 \\
\hline & 4M3-1 & $820 *$ & 870 & 258 & 10 & 112 \\
\hline & 4M3-2 & $1107 *$ & $936 *$ & 293 & 14 & 188 \\
\hline \multirow{3}{*}{$\begin{array}{l}\text { Elongation } \\
(\%)\end{array}$} & $720 \mathrm{Li}$ & 14 & 40 & 31 & 19.5 & 37 \\
\hline & 4M3-1 & $0.35 \%$ & 36 & 14.1 & 5 & 28 \\
\hline & 4M3-2 & $0.55 *$ & $1.8 *$ & 18 & 5.3 & 21 \\
\hline \multirow{3}{*}{$\begin{array}{l}\text { Reduction in area } \\
(\%)\end{array}$} & $720 \mathrm{Li}$ & 13 & 64 & 39 & 23 & 60 \\
\hline & 4M3-1 & $0.5 *$ & 63 & 25 & 10 & 56 \\
\hline & 4M3-2 & $1 *$ & $2 *$ & 25 & 8 & 28 \\
\hline
\end{tabular}

* The test was interrupted. 

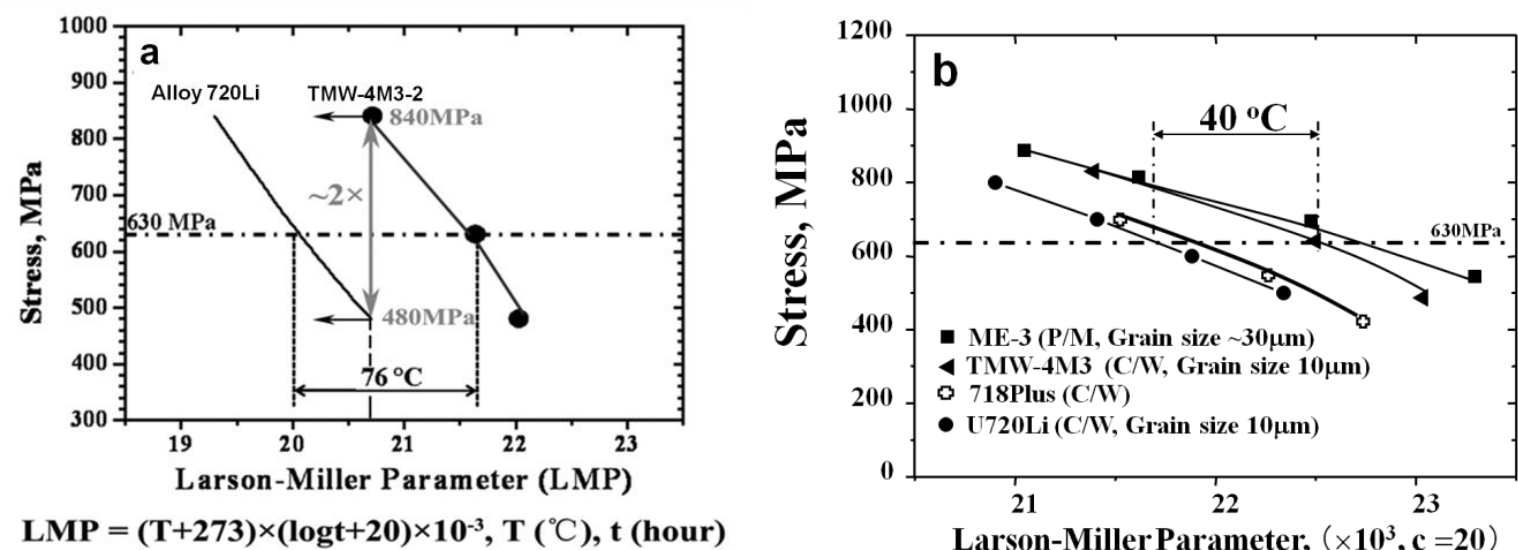

Figure 5. Larson-Miller stress-life plot for (a) life to $0.2 \%$ creep strain; (b) rupture life of TMW-4M3 alloy in comparison with reported U720Li ${ }^{[6]}$, 718Plus ${ }^{[7]}$ and $\mathrm{ME}^{[8]}$

a temperature gain of about $76{ }^{\circ} \mathrm{C}$ can be expected from TMW4M3-2 alloy by using of Larson-Miller parameter approach commonly employed for disk alloys (Figure 5a). Meanwhile, for the same $0.2 \%$ creep strain life (Figure 5a), the loading stress of TMW-4M3 was nearly twice as much as that of Alloy U720Li. The Larson-Miller comparison of rupture life for TMW-4M3 alloys along with those of U720Li [7], 718 PLUS [8] and ME3
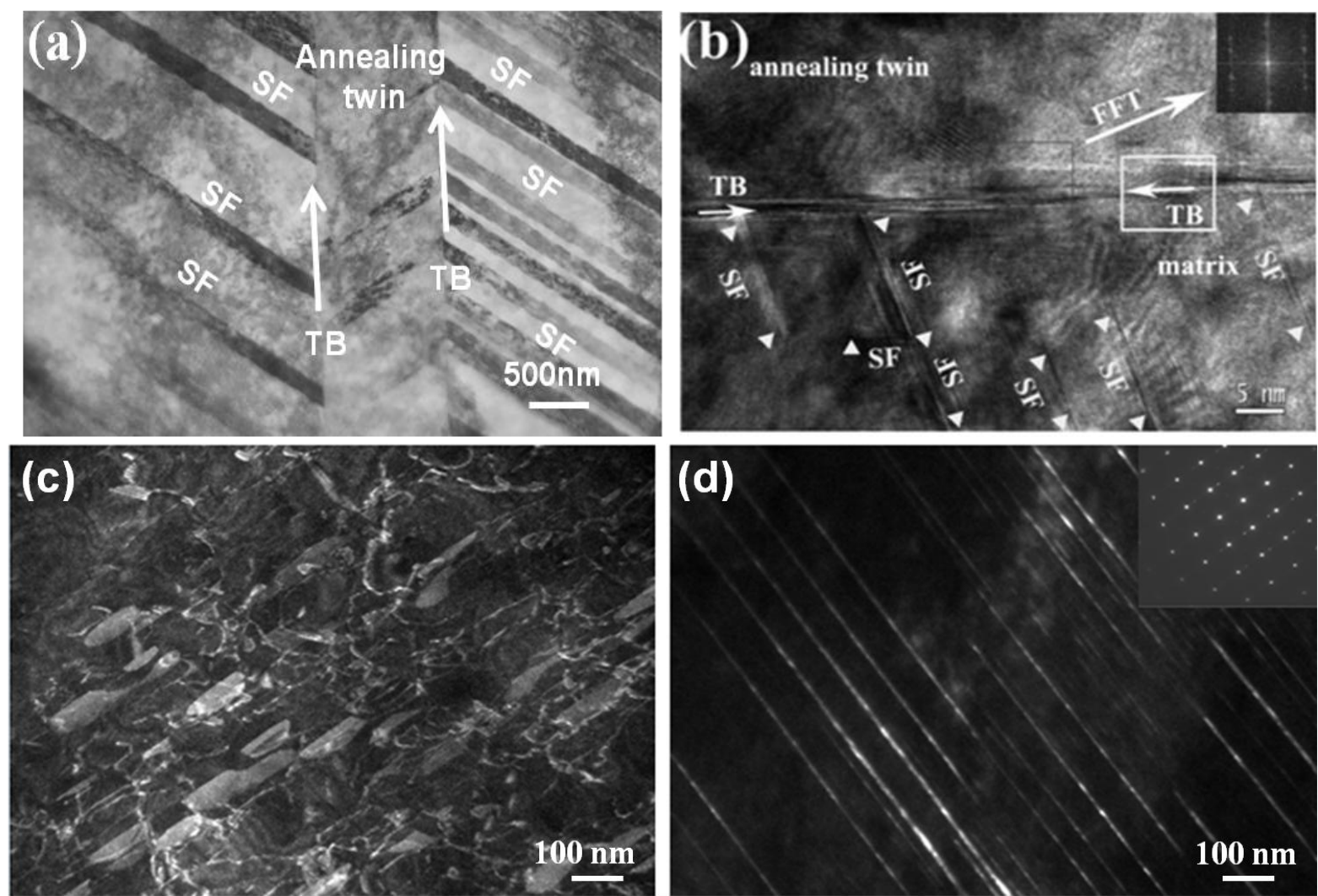

Figure 6. TEM micrographs showing the deformation substructures after tensile tested at $725{ }^{\circ} \mathrm{C}$ in (a) TMW-4M3, (b) TMW-4M3, (c) Alloy 720Li, (d) TMW-4M3 alloy [9] (also known as Rene 104, with grain size of about 30 $\mu \mathrm{m})$ shows that TMW-4M3 can be comparable with ME3 alloy at higher stress level (Figure 5b).

Representative TEM micrographs of the tensile tested samples are shown in Figures 6. The significant observation here is that the nano-scale coherent twin boundaries (TBs) as a result of high 
density annealing twins supply additional barriers to the movement of dislocation, and the dislocations could not penetrate directly through TBs during deformation (Figures $6 \mathrm{a}$ and $6 \mathrm{~b}$ ). In Alloy $720 \mathrm{Li}$, shearing of $\gamma^{\prime}$ precipitates by super-dislocation pairs was the dominant deformation model up to $725^{\circ} \mathrm{C}$ (Figure 6C). In TMW-4M3 alloy, the deformation model was the same as that in Alloy $720 \mathrm{Li}$ at $25^{\circ} \mathrm{C}$. However, at $725^{\circ} \mathrm{C}, \gamma^{\prime}$ precipitates were mainly cut by stacking faults and deformation twins (Figure $6 \mathrm{~d}$ ).

Generally speaking, superalloys develop high temperature strength through solid solution strengthening, precipitate hardening and grain boundary strengthening. Compared with Alloy 720Li, TMW-4M3-2 alloy has similar grain size and lower contents of solid solution strengthening elements such as W and Mo. Therefore, the improvement in the strength of TMW-4M3 may mainly contribute from its higher $\gamma^{\prime}$ volume fraction and its large number of annealing twin boundaries (TBs). Because the distribution and the size of the tertiary $\gamma^{\prime}$ precipitates in all tested alloys were not significantly affected by the heat treatment conditions (Table IV), the increase of the fractions of secondary $\gamma^{\prime}$ precipitates and TBs was very likely responsible for the strength improvement at high temperatures, which implies a novel strategy for enhancing high-temperature strength in disk superalloys [10].
Low Cycle Fatigue (LCF) and Fatigue Crack Growth (FCG) Properties

LCF tests were conducted under strain control condition using a triangular waveform with a frequency of $0.5 \mathrm{~Hz}$ over a wide range of total strain amplitude of $0.8 \%$ to $1.2 \%$ and strain ratio $\mathrm{R}_{\varepsilon}=$ $\varepsilon_{\min } / \varepsilon_{\max }=0$ on smooth cylindrical specimens at $650^{\circ} \mathrm{C}$ and $725^{\circ} \mathrm{C}$. Normally, the peak stresses as a function of cumulative strain did not essentially change during cycling and the stress amplitude dropped rapidly at the end period of the test in TMW-4M3 alloy (Figure 7a), which indicates that most of the fatigue life was used to initiate crack.

It is obvious that the TMW-4M3 exhibits higher fatigue life at lower strain amplitudes at both $650^{\circ} \mathrm{C}$ and $725^{\circ} \mathrm{C}$ (Figures $7 \mathrm{~b}$ and $7 \mathrm{c})$. The benefit difference in fatigue life, however, narrows down at higher strain amplitudes and is comparable at $650^{\circ} \mathrm{C}$ and $725^{\circ} \mathrm{C}$ under $\triangle \varepsilon_{\mathrm{t}}=1.2 \%$

FCG tests were carried out in air at $650^{\circ} \mathrm{C}$ and $725^{\circ} \mathrm{C}$ for stress ratios of $\mathrm{R} \sigma=0.05$ and $0.5\left(\mathrm{R} \sigma=\sigma_{\min } / \sigma_{\max }\right)$ by using compacttension specimens (CT) (12.7 mm in thickness, $61 \mathrm{~mm}$ in width). All specimens were pre-cracked at room temperature at a
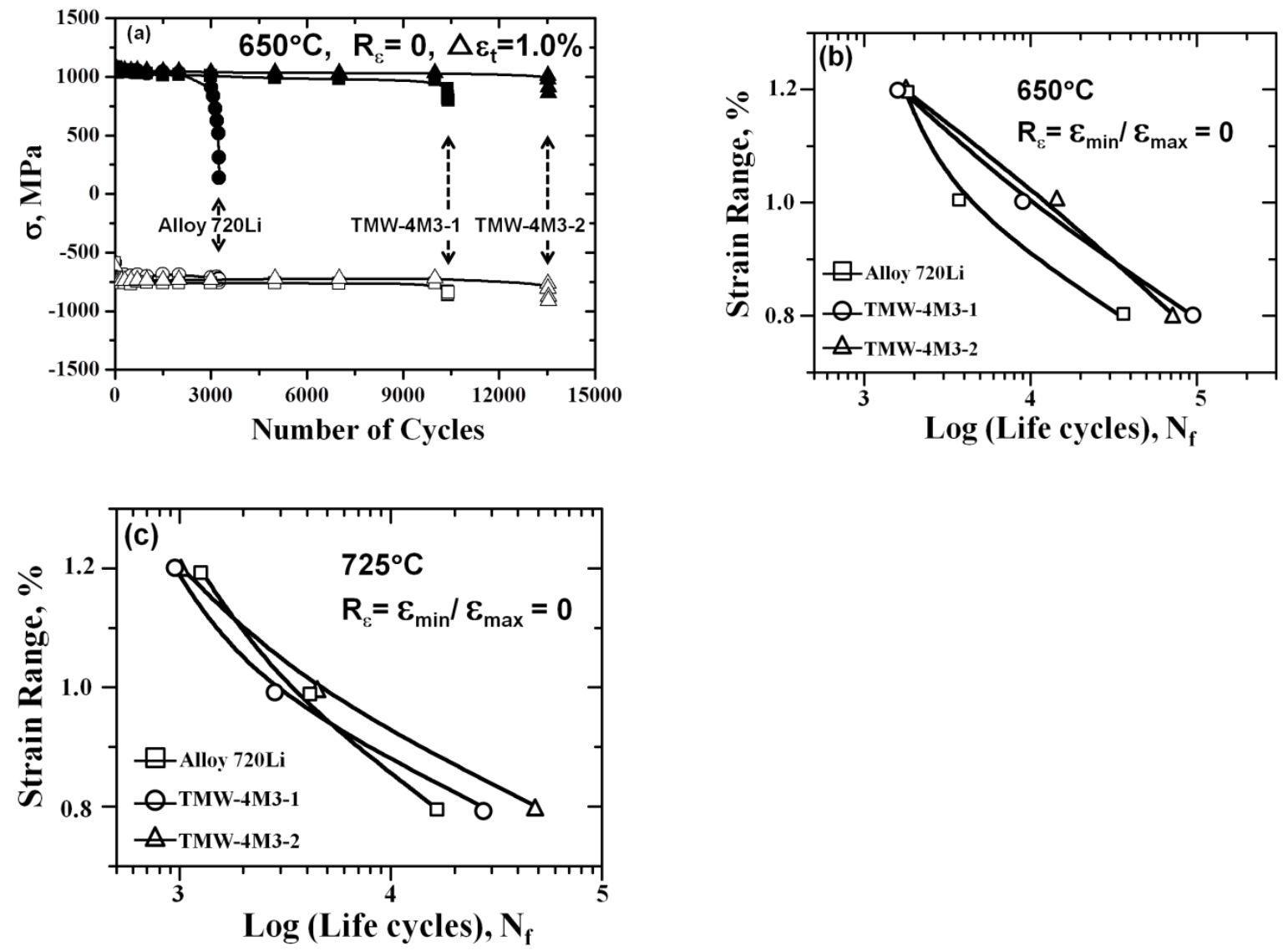

Figure 7. Dependence of fatigue life $\left(N_{f}\right)$ on strain range $\left(\Delta \varepsilon_{\mathrm{t}}\right)$ of TMW-4M3 and Alloy 720Li 
frequency of $20 \mathrm{~Hz}$. A closed-loop servo-hydraulic testing machine with specimens cycled under stress-intensity $(K)$ control (a symmetric, triangular waveform with a frequency of $2 \mathrm{~Hz}$ and various load ratios). During the tests, crack-length measurements were determined from the unloading elastic compliance measured by a capacitance gage mounted across the notch mouth. Stress intensities were determined from the linear-elastic solutions for the CT geometry given in ASTM Standard E-399.

Figure 8 shows schematically the crack growth rate $d a / d N$ as a function of the stress intensity factor range $\Delta K$ at $650^{\circ} \mathrm{C}$ and 725 ${ }^{\circ} \mathrm{C}$ for $\mathrm{R}=0.05$ and 0.5 in a $\log$ - $\log$ scale. Assuming the Paris law
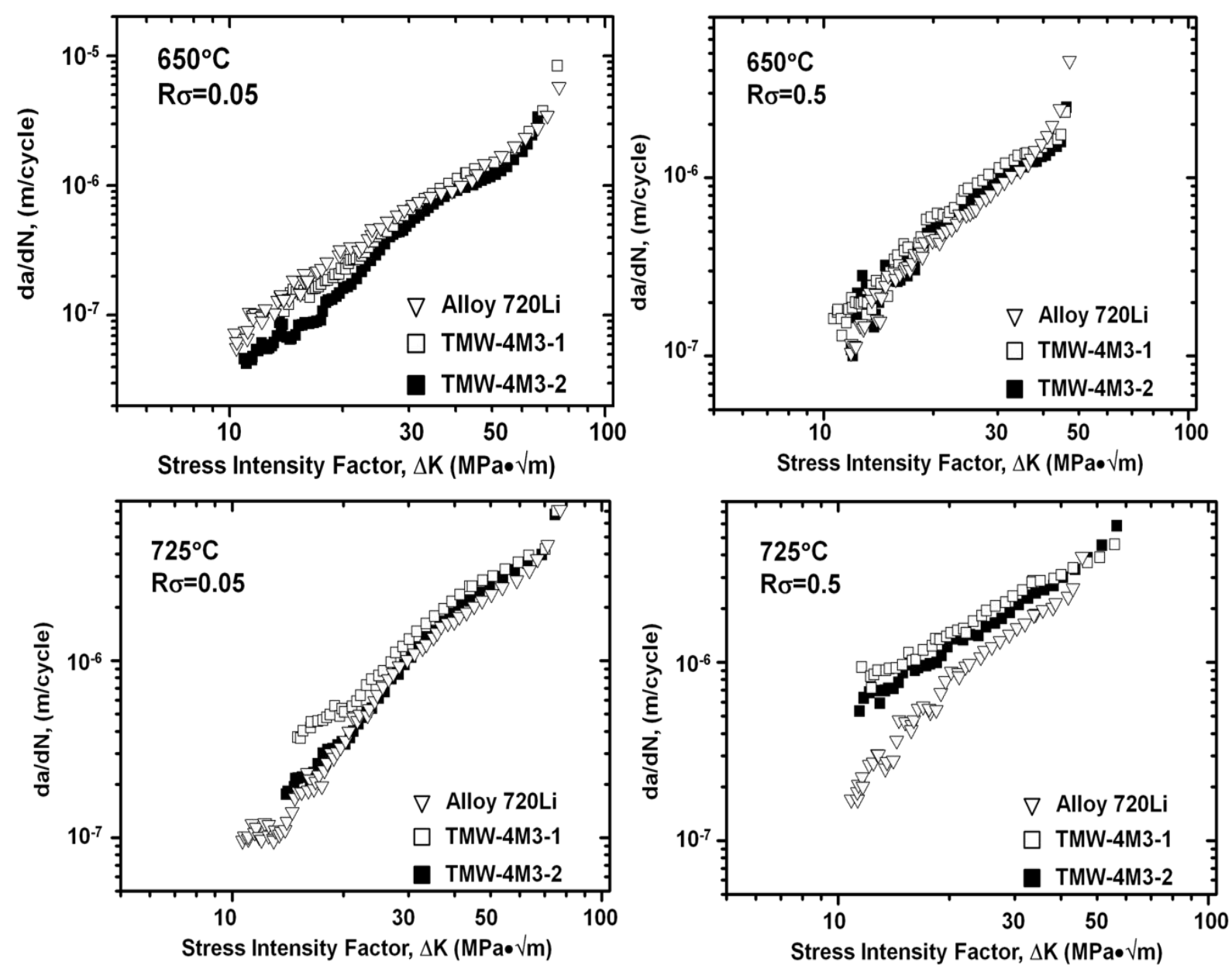

Figure 8. Cyclic fatigue crack growth rates tested at $650^{\circ} \mathrm{C}$ and $725^{\circ} \mathrm{C}$ for a stress ratios $\mathrm{R} \sigma=0.05$ and 0.5 .

Table VII. $C$ and $m$ Values Determined from $d a / d N$ versus $\Delta K$ Plots for the Tested Alloys.

\begin{tabular}{|c|c|c|c|c|c|c|c|c|}
\hline \multirow{3}{*}{ Alloy } & \multicolumn{4}{|c|}{$650^{\circ} \mathrm{C}$} & \multicolumn{4}{|c|}{$725^{\circ} \mathrm{C}$} \\
\hline & \multicolumn{2}{|c|}{$\mathrm{R}=0.05$} & \multicolumn{2}{|c|}{$\mathrm{R}=0.5$} & \multicolumn{2}{|c|}{$\mathrm{R}=0.05$} & \multicolumn{2}{|c|}{$\mathrm{R}=0.5$} \\
\hline & $\mathrm{C}$ & $\mathbf{m}$ & $\mathrm{C}$ & $\mathbf{m}$ & $\mathrm{C}$ & $\mathbf{m}$ & $\mathrm{C}$ & $\mathbf{m}$ \\
\hline Alloy $720 \mathrm{Li}$ & $7.90 \times 10^{-10}$ & 1.96 & $9.78 \times 10^{-10}$ & 2.02 & $4.10 \times 10^{-10}$ & 2.24 & $2.07 \times 10^{-9}$ & 1.94 \\
\hline TMW-4M3-1 & $4.97 \times 10^{-10}$ & 2.06 & $1.96 \times 10^{-9}$ & 1.84 & $2.89 \times 10^{-9}$ & 1.77 & $4.31 \times 10^{-8}$ & 1.17 \\
\hline TMW-4M3-2 & $1.62 \times 10^{-10}$ & 2.31 & $2.00 \times 10^{-9}$ & 1.79 & $6.18 \times 10^{-10}$ & 2.14 & $2.34 \times 10^{-8}$ & 1.31 \\
\hline
\end{tabular}


is applicable to the tested alloys, the slope (m value) and constant $\mathrm{C}$ values for Paris regime, where FCGR behavior is represented by $d a / d N=\mathrm{C}(\triangle \mathrm{K})^{\mathrm{m}}$, were compared for Alloy 720Li and TMW4M3 at various testing conditions in Table VII. At a given test condition, the $\mathrm{m}$ and $\mathrm{C}$ values for Alloy 720Li and TMW-4M3 alloy were comparable. The FCGRs of both Alloy 720Li and TMW-4M3 alloys were similar except the result at $725^{\circ} \mathrm{C}$ for $\mathrm{R}=$ 0.5 , where Alloy U720Li had lower FCGR when $\Delta K$ was below about $50 \mathrm{MPa} \sqrt{\mathrm{m}}$ (Figure $8 \mathrm{~d}$ ). This may be caused by the lower $\mathrm{Cr}$ content of TMW-4M3, which may decrease its oxidation resistance at high temperatures and long exposure time during tested at high $R$ value.

\section{Summary \& Conclusions}

The paper evaluates the thermal phase stability and mechanical properties of two C\&W disk superalloys, TMW-4M3 and Alloy U720Li. It is shown that TMW-4M3 alloy has about 100MPa higher yield strength compared with Alloy U720Li at $750^{\circ} \mathrm{C}$ and can provide at least $40^{\circ} \mathrm{C}$ temperature advantage in creep-rupture performance over Alloy U720Li loaded under 630MPa. The resistances to $\mathrm{LCF}$ and FCGR are better at $650^{\circ} \mathrm{C}$ for TMW-4M3 and are comparable at $725^{\circ} \mathrm{C}$. Meanwhile, a higher solution temperature over Alloy $720 \mathrm{Li}$ is beneficial for TMW-4M3 alloy to get superior mechanical properties, which implies that further enhancement of properties in this alloy is possible. These results indicate that TMW-4M3 is a promising $\mathrm{C} \& \mathrm{~W}$ disk material for turbine applications beyond $700^{\circ} \mathrm{C}$.

\section{Acknowledgements}

Partial financial support by the New Energy and Industrial Technology Development Organization (NEDO) of Japan is gratefully acknowledged. The authors are grateful the supply of materials for this research from Mitsubishi Materials Corporation and the support of mechanical property testing from Kobe Materials Testing Laboratory Co., Ltd.

\section{References}

1. Y. F. Gu et al., "New Ni-Co-base Disk Superalloys with Higher Strength and Creep Resistance," Scripta Materialia, 55 (2006), 815-818.

2. Y. F. Gu et al., "Development of Ni-Co-base Alloys for HighTemperature Disk Application," Superalloys 2008, ed. Roger C. Reed et al. (Warrendale, PA, USA: TMS, 2008), 53-61.

3. Y. F. Gu et al., "Comparison of Mechanical Properties of TMW Alloys, New Generation of Cast-and-wrought Superalloys for Disk Application," Metall. Mater. Trans. A, 40 (2009), 3047-3050.

4. H. Harada et al., "Heat-resistance Superalloy," European Patent, EP 1842934, October 19, 2011.

5. C. Y. Cui et al., "Microstructural Evolution and Mechanical Properties of a Ni-base Superalloy, TMW-4," Metall. Mater. Trans. A, 40 (2009), 282-291.

6. Y. Yuan et al., "Influence of Co Content on Stacking Fault Energy in Ni-Co Base Disk Superalloys," J. Mater. Res., 26 (2011), 2833

7. Xiao X, Zhou LZ and Guo JT, "Microstructural Stability and
Creep Behavior of Nickel Base Superalloy U720Li,” Acta Metall. Sinca, 37(11) (2001), 1159-1164.

8. W. D. Cao and R. Kennedy, "Role of Chemistry in 718-type Alloys-Allvac ${ }^{\circledR} 718$ Plus ${ }^{\mathrm{TM}}$ Alloy Development," Superalloys 2004, ed. K. A. Green et. al. (Warrendale, PA, USA: TMS, 2004), 91-99.

9. Timothy P. Gabb et al., "Characterization of the Temperature Capabilities of Advanced Disl Alloy ME3," (Report NASA TM 2002-211796, August 2002).

10. Y. Yuan et al., "A Novel Strategy for the Design of Advanced Engineering Alloys - Strengthening Turbine Disk Superalloys via Twinning Structures," Adv. Eng. Mater., 13 (2011), 296-300. 